\title{
Polycations increase the permeability of Mycobacterium vaccae cell envelopes to hydrophobic compounds
}

\author{
Małgorzata Korycka-Machała, ${ }^{1}$ Andrzej Ziółkowski, ${ }^{1}$ \\ Anna Rumijowska-Galewicz, ${ }^{1}$ Katarzyna Lisowska ${ }^{2}$ \\ and Leon Sedlaczek ${ }^{1}$
}

Author for correspondence: Leon Sedlaczek. Tel: +48 42 6492263. Fax: + 48426491633. e-mail: lsedlacz@cmiwpan.lodz.pl

1 Centre for Microbiology \& Virology, Polish Academy of Sciences, 93-232 Łódź, Lodowa 106, Poland

2 University of Łódź, Institute of Microbiology and Immunology, Department of Industrial Microbiology, 90-237 Łódź, Banacha 12/16, Poland
Polycations [protamine, polymyxin B nonapeptide (PMBN) and polyethyleneimine (PEI)] have been shown to increase the cell wall permeability of Mycobacterium vaccae to highly hydrophobic compounds, as manifested in enhanced intracellular bioconversion of $\beta$-sitosterol to 4androsten-3,17-dione (AD) and 1,4-androstadien-3,17-dione (ADD), and cell sensitization to erythromycin and rifampicin. The quantity of $A D(D)$ formed per biomass unit was twice as high in the presence of PMBN and PEI, and three times higher with protamine. The sensitization factor, i.e. the $\mathrm{MIC}_{50}$ ratio of the control bacteria to those exposed to polycations, ranged from 4 to 16, depending on the polycation/antibiotic combination. Non-covalently bound free lipids were extracted from the control and polycation-treated cells and fractionated with the use of chloroform, acetone and methanol. Chloroformand acetone-eluted fractions (mainly neutral lipids and glycolipids, respectively) showed significant polycation-induced alterations in their quantitative and qualitative composition. The fatty acid profile of neutral lipids was reduced in comparison to control, whereas acetone-derived lipids were characterized by a much higher level of octadecenoic acid $\left(\mathrm{C}_{18: 1}\right)$ and a considerably lower content of docosanoic acid $\left(C_{22: 0}\right)$, the marker compound of mycolate-containing glycolipids. Methanol-eluted fractions remained unaltered. Cell-wall-linked mycolates obtained from delipidated cells were apparently unaffected by the action of polycations, as judged from the TLC pattern of mycolic acid subclasses, the mean weight of mycolate preparations and the $\mathrm{C}_{22: 0}$ acid content in the mycolates, determined by GC/MS and pyrolysis GC. The results suggest the involvement of the components of non-covalently bound lipids in the outer layer in the $M$. vaccae permeability barrier.

Keywords: cell wall permeability, polycationic compounds, mycolates, free lipids

\section{INTRODUCTION}

Richness in lipidic compounds, as well as their composition and organization, are the most distinctive features of the mycobacterial cell wall (Besra \& Chatterjee, 1994; Brennan, 1988; Daffé \& Draper, 1998). There is growing evidence that these compounds form a

Abbreviations: $A D, 4$-androsten-3,17-dione; $A D D$, 1,4-androstadien3,17-dione; $F(M) A M E$, fatty (mycolic) acid methyl ester; OM, outer membrane; PEl, polyethyleneimine; PMBN, polymyxin B nonapeptide. unique asymmetric bilayer, which is considered to be responsible for the extremely low permeability of the cell wall to both hydrophilic and hydrophobic substances (Jarlier \& Nikaido, 1990; Liu et al., 1995; Minnikin, 1982; Nikaido et al., 1993).

The outer monolayer consists of complex polar and non-polar free lipids, which include a number of species- and type-specific glycolipids, glycopeptidolipids, sulpholipids, glycerophospholipids, phenolic glycolipids, lipoarabinomannan, trehalose dimycolates, phtiocerol dimycocerosate, acylglycerides and others 
(Besra \& Chatterjee, 1994; Brennan \& Nikaido, 1995; Daffé \& Draper, 1998). The polar head groups of these lipids are exposed on the cell surface, whereas the lipidic components, composed of short-chain or intermediatechain hydrocarbons, interact with the longer meromycolate branch or shorter $\alpha$-branch hydrocarbon chains of the underlying mycolic acids (Brennan \& Nikaido, 1995; Nikaido et al., 1993).

Mycolic acids, the most characteristic lipid components of mycobacterial cell envelopes, are high-molecularmass $\alpha$-alkyl $\beta$-hydroxy fatty acids containing 70 to 90 carbon atoms. Biophysical studies, including X-ray diffraction analysis performed on purified cell wall of Mycobacterium chelonae, revealed that the hydrocarbon chains of mycolic acids form a highly ordered, close-packed quasicrystalline layer of abnormal thickness, perpendicular to peptidoglycan, and they function as an effective permeability barrier to solutes (Nikaido et al., 1993). Differential scanning calorimetry demonstrated that a major portion of these lipids occurred in a structure of extremely low fluidity in the growing cells, which may account for the low permeability (Liu et al., 1995). Electron spin resonance techniques (Liu et al., 1995, 1996) and fluorescent molecular probes (Christensen et al., 1999) provided further evidence for a lipidic bilayer located externally to the conventional plasma membrane and organized into lipid domains of different hydrophobicity and permeability features.

The asymmetric lipid bilayer, extremely impermeable to hydrophilic and hydrophobic compounds, corresponds to a mycobacterial external membrane, in a way analogous to the outer membrane (OM) in Gramnegative bacteria (Christensen et al., 1999). The latter, composed of lipopolysaccharide (LPS) and glycerophospholipid layers, is another asymmetric lipid bilayer which is only slowly penetrated by hydrophobic compounds, quasicrystalline LPS being the limiting structure. The permeability of the OM was shown to be up to 100-fold lower than that of the cell membrane composed of usual glycerophospholipid bilayers (Plesiat \& Nikaido, 1992).

As shown in a number of papers summarized by Vaara (1992), the permeability of the OM could be increased by the action of polycationic peptides, which was manifested by significant sensitization of Gram-negative bacteria to hydrophobic antibiotics. Apart from peptides, polyethyleneimine produced a similar effect (Helander et al., 1997, 1998).

Although the mycobacterial asymmetric bilayer has a different chemical composition and architecture than the OM of Gram-negative bacteria, it could also be partially disintegrated by the action of polycations. The outer leaflet contains negatively charged components to which polycationic compounds may potentially bind. This could, in turn, induce local disintegration of the native cell wall architecture, resulting in a change to its physiological features, including permeability.

The aim of our study was to test this possibility and to prove whether polycations can be used to alter mycobacterial cell wall permeability by means of a deliberate procedure. Only a few papers have been devoted to the mycobacterial cell wall structure-topermeability relationship, despite its crucial importance in the context of the multiple drug resistance of pathogenic strains and the application of saprophytic members of the genus Mycobacterium in a number of biotechnological processes.

In the present study we show that Mycobacterium vaccae, treated with polycationic compounds at subinhibitory concentrations which do not affect mycolic acids, performed the intracellular degradation of the $\beta$ sitosterol side chain at a higher rate and, in addition, it exhibited increased susceptibility to antimycobacterial agents. The analysis of the non-covalently linked free lipids showed profound alterations to their fatty acid composition, which indicates partial disorganization of the cell wall outer lipid layer.

\section{METHODS}

Bacterial strain and medium. Mycobacterium sp. NRRL MB 3683 was used, a mutant strain capable of selectively cleaving the side chain of $\beta$-sitosterol, yielding 4-androsten-3,17-dione (AD) and 1,4-androstadien-3,17-dione (ADD) as the bioconversion products in a ratio of $10: 1$. A comparison with Mycobacterium vaccae SN 920 and SN 994, the reference strains in the Reference Laboratory for the genus at the Forschungszentrum Borstel, Germany, confirmed that the strain was a member of the species M. vaccae. When digested with endonucleases BstEI and HaeIII, the amplification products obtained for the $h s p 65$ gene, which is used for differentiating mycobacterial strains, revealed the same patterns for the three micro-organisms compared (Brzostek et al., 2001).

In all experiments for cell growth, sterol degradation and drug sensitivity assays, the organism was grown on NB medium containing $\left(\mathrm{g} \mathrm{l}^{-1}\right)$ : nutrient broth (Difco), 8.0; glucose, 10.0; supplemented with Tween $80,0 \cdot 2 \%(\mathrm{v} / \mathrm{v})$. After autoclaving, the medium $\mathrm{pH}$ was $6 \cdot 0-6 \cdot 2$. The bacteria were maintained on slants on NB medium solidified with $2 \%(\mathrm{w} / \mathrm{v})$ agar (Difco).

Materials. $\beta$-Sitosterol, which contained $16 \% \quad(\mathrm{w} / \mathrm{w})$ campesterol, was obtained from Triple Crown (Sweden); AD and ADD were obtained from Koch-Light; cholesterol was from Serva; androst-1-ene-3,11,17-trione, mycolic acids from Mycobacterium tuberculosis as reference compounds, erythromycin and rifampicin were purchased from Sigma. Polycationic compounds used in this study were representative for peptides (protamine), derivatives of peptides which are not bactericidal (polymyxin B nonapeptide, PMBN) and nonpeptide compounds (polyethyleneimine, PEI of mean molecular mass $60000 \mathrm{Da}$ ); they were all obtained from Sigma. All other chemicals used were of reagent grade.

Permeability assay based on the rate of $\beta$-sitosterol transformation to $\operatorname{AD}(D)$. The selective side-chain degradation of $\beta$ sitosterol proceeds intracellularly, catalysed by an enzyme complex, a part of which is involved in fatty acid $\beta$-oxidation (Szentirmai, 1990). The substrate must permeate the cell wall to be transformed to androstene derivatives $\mathrm{AD}(\mathrm{D})$. The latter are stable products that can be accurately determined by GC. The rate of $\mathrm{AD}(\mathrm{D})$ formation and accumulation is thus a measure of sterol penetration rate for normal cells, as well as 
those whose cell wall permeability has been altered by means of deliberate procedures.

Growth and $\boldsymbol{\beta}$-sitosterol transformation. NB medium $(100 \mathrm{ml}$ in 1 litre flasks) was inoculated with M. vaccae MB 3683 washed off from $48 \mathrm{~h}$ cultures on agar slants and incubated for $48 \mathrm{~h}$ at $32{ }^{\circ} \mathrm{C}$ with shaking at 180 r.p.m. From this culture, $10 \mathrm{ml}$ was transferred to $90 \mathrm{ml} \mathrm{NB}$ medium in 1 litre flasks. At the time of inoculation, $\beta$-sitosterol $\left(0 \cdot 2 \mathrm{~g} \mathrm{l}^{-1}\right)$, prepared by homogenization as described previously (Sedlaczek et al., 1994), and one of the polycations were added to the medium, which was then incubated under the conditions described above. The concentration of polycations is shown in Results for the individual configurations. Control cultures did not contain polycationic agents. To determine the cell dry mass, samples $(2 \times 5 \mathrm{ml})$ were withdrawn from the culture at the start of the experiments and at $24 \mathrm{~h}$ intervals, they were filtered through Synpor filters (pore diameter $0 \cdot 2 \mu \mathrm{m}$ ) of known weight and the sediment was dried to constant weight. The progress in $\beta$-sitosterol side-chain degradation was determined in $2 \mathrm{ml}$ culture samples to which cholesterol and androst-1ene-3,11,17-trione as internal standards were added (each at $100 \mu \mathrm{g}$ in $50 \mu \mathrm{l}$ chloroform) and extracted three times with an equal volume of chloroform. The extracts were dried under vacuum; the residue was dissolved in $0.5 \mathrm{ml}$ acetone and steroids were analysed using a Hewlett Packard 5890 Ser II chromatograph as described previously (Rumijowska et al., 1997).

Drug sensitivity assay. Twofold dilution series were prepared in $4.5 \mathrm{ml} \mathrm{NB}$ medium in glass tubes, from sterile stock solutions of $0.25 \mathrm{mg}$ erythromycin $\mathrm{ml}^{-1}$ and $0.20 \mathrm{mg}$ rifampicin $\mathrm{ml}^{-1}$. The final drug concentrations ranged from 25 to $0.045 \mu \mathrm{g} \mathrm{ml}^{-1}$ and from 20 to $0.08 \mu \mathrm{g} \mathrm{ml}^{-1}$, respectively. The tested polycationic compound was added to each tube at a previously determined concentration that did not affect growth and the medium was inoculated in a $24 \mathrm{~h}$ liquid culture and incubated as described above. Bacterial growth was monitored spectrophotometrically (Specol 20; Carl Zeiss) at $560 \mathrm{~nm}$. To test the effect of the drug alone and in combination with the polycationic compound, samples $(0.5 \mathrm{ml})$ were removed at the start and after 24 and $48 \mathrm{~h}$, diluted adequately and $\mathrm{OD}_{560}$ was measured. The initial $\mathrm{OD}_{560}$ was $0 \cdot 1-0 \cdot 15$. Cultures containing polycation alone and those without any supplement were also analysed. From the relationship between $\mathrm{OD}_{560}$ and bacterial mass content in the samples, $\mathrm{MIC}_{50}$ was determined for the drug alone and in combination with polycations.

\section{Lipid analysis}

(i) Extraction of free lipids. Lyophilized control and polycationtreated cells $(2 \mathrm{~g})$ were extracted three times with chloroform/ methanol $(2: 1, \mathrm{v} / \mathrm{v})$ for $48 \mathrm{~h}$ at room temperature. The proportion of cells to solvent $(\mathrm{w} / \mathrm{v})$ in the successive extractions was $1: 400,1: 200$ and $1: 100$. Extracts were combined, concentrated, washed with water, evaporated to dryness under nitrogen at room temperature and analysed. Defatted cells were dried and kept for further treatment.

(ii) Separation of lipid fractions. Crude free lipids from control and polycation-treated cells $(230 \mathrm{mg})$ were fractionated on a column $(30 \times 700 \mathrm{~mm})$ of activated silica gel (silica gel 60 , 70-230 mesh; Merck), and chloroform (800 ml), acetone $(1600 \mathrm{ml})$ and methanol $(800 \mathrm{ml})$ were used as eluants (Gamian et al., 1996). The eluates (each 200-300 ml) were monitored for various types of lipids on TLC silica gel $60 \mathrm{~F}_{254}$ plates (Merck) using chloroform/methanol/water $(65: 25: 4$, by vol.). The positions of the separated compounds were detected by spraying with a $5 \%(\mathrm{w} / \mathrm{v})$ ethanolic solution of molybdophosphoric acid, followed by heating for $10 \mathrm{~min}$ at $180^{\circ} \mathrm{C}$ (visualization of all lipid-containing compounds) (Ariza et al., 1994). To detect sugar-containing lipids, the plates were sprayed with orcinol $\left(0.5 \%\right.$, w/v, in $3 \% \mathrm{H}_{2} \mathrm{SO}_{4}$ in methanol) followed by heating. Dittmer-Lester reagent was used for revealing phosphorus-containing components.

Fractions containing similar compounds eluted by the same solvent were combined and analysed separately for fatty acid methyl ester (FAME) profiles, as described in our previous study (Rumijowska-Galewicz et al., 2000).

(iii) Analysis of mycolic and fatty acids. Mycolic acids were determined in methanolysates of lyophilized whole cells and delipidated cells. Fatty acids were analysed in free lipids, lipid fractions eluted from the silica gel 60 column and the aftergrowth medium of control and polycation-treated cultures. Methanolysis was performed in sealed Pyrex glass tubes, in a mixture of dry methanol/toluene/conc. sulphuric acid (30:15:1, by vol.) at $75^{\circ} \mathrm{C}$ for $18 \mathrm{~h}$, according to Minnikin et al. (1980). The mycolic acid methyl esters (MAMEs) and FAMEs formed were extracted twice with hexane, the extracts were combined, filtered through a short column of ammonium hydrogen carbonate and dried under nitrogen. The MAMEs and FAMEs were separated on Merck silica gel 60 TLC plates using hexane/ethyl acetate $(94: 6, \mathrm{v} / \mathrm{v})$ as solvent system. The positions of the separated compounds were detected by spraying with a $10 \%$ ethanolic solution of molybdophosphoric acid, followed by heating for $10 \mathrm{~min}$ at $180^{\circ} \mathrm{C}$.

For preliminary quantification of mycolates, purified dried extracts of methanolysates (triplicate samples) were determined by weighing and subjected to GC/MS and pyrolysis GC procedures for the analysis of their fatty acids and related compounds.

\section{RESULTS}

\section{The effect of polycationic compounds on $\beta$-sitosterol bioconversion}

Cell growth and the formation of $\beta$-sitosterol side-chain cleavage products is shown in Table 1.

At the concentrations applied, selected in earlier experiments, potential permeabilizing agents either had no effect on the cell biomass increase, or inhibited cell growth only to a small extent. In cultures exposed to protamine, the final cell biomass was about $70 \%$ that of the control. The inhibitory effect of PEI was less significant, but in the presence of PMBN, cell growth was comparable to the control.

Despite a lower increase in cell mass, the accumulation of $\beta$-sitosterol bioconversion products was distinctly higher in protamine- and PEI-treated cultures, amounting to approximately 130 and $150 \%$ of the control level, respectively. Also, in the culture exposed to PMBN, which had no noticeable effect on cell growth, the formation of $\mathrm{AD}(\mathrm{D})$ was evidently enhanced. The time course of $\mathrm{AD}(\mathrm{D})$ production differed, depending on the individual polycation. With protamine, the partial growth inhibition resulted in retardation of the bioconversion process during the first $24 \mathrm{~h}$ interval. The 
Table 1. The effect of polycationic compounds on growth and $\beta$-sitosterol transformation of $M$. vaccae MB 3683

Data are of a representative experiment. Quantitative estimation of $\beta$-sitosterol bioconversion was made for several independent experiments. Although some variations in the bioconversion rate resulted in various intensities of $\mathrm{AD}(\mathrm{D})$ accumulation, in each experiment the activity of polycationtreated cells [i.e. formation of $\mathrm{AD}(\mathrm{D})$ per biomass unit] was evidently higher.

\begin{tabular}{|c|c|c|c|c|c|c|c|c|c|}
\hline \multirow{3}{*}{$\begin{array}{l}\text { Growth and } \\
\text { transformation } \\
\text { time }(h)\end{array}$} & \multicolumn{3}{|c|}{$\begin{array}{l}\text { Cell biomass increase } \\
\qquad\left(\mathrm{g} \text { dry wt } \mathrm{l}^{-1}\right)^{*}\end{array}$} & \multicolumn{3}{|c|}{$\begin{array}{c}\mathrm{AD}(\mathrm{D}) \text { accumulation } \\
\left(\mathrm{mg} \mathrm{l}^{-1}\right)\end{array}$} & \multicolumn{3}{|c|}{ 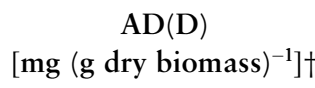 } \\
\hline & \multicolumn{9}{|c|}{ (a) Protamine concn $\left(\mu \mathrm{g} \mathrm{ml}^{-1}\right)$} \\
\hline & $\mathbf{0}$ & 30 & 40 & $\mathbf{0}$ & 30 & 40 & $\mathbf{0}$ & 30 & 40 \\
\hline 0 & $0 \cdot 5$ & $0 \cdot 5$ & $0 \cdot 5$ & 0 & 0 & 0 & 0 & 0 & 0 \\
\hline 24 & $2 \cdot 1$ & $1 \cdot 4$ & $1 \cdot 3$ & $13 \cdot 6$ & 0 & 0 & $6 \cdot 5$ & 0 & 0 \\
\hline 48 & $2 \cdot 7$ & $1 \cdot 5$ & $1 \cdot 4$ & $78 \cdot 8$ & $102 \cdot 0$ & $112 \cdot 0$ & $24 \cdot 1$ & $69 \cdot 9$ & $79 \cdot 4$ \\
\hline \multirow[t]{3}{*}{72} & $3 \cdot 2$ & $2 \cdot 3$ & $2 \cdot 3$ & $111 \cdot 1$ & $146 \cdot 5$ & $144 \cdot 4$ & $10 \cdot 1$ & $19 \cdot 1$ & $14 \cdot 1$ \\
\hline & \multicolumn{9}{|c|}{ (b) PEI concn $\left(\mu \mathrm{g} \mathrm{ml}^{-1}\right)$} \\
\hline & $\mathbf{0}$ & $2 \cdot 5$ & 5 & $\mathbf{0}$ & $2 \cdot 5$ & 5 & $\mathbf{0}$ & $2 \cdot 5$ & 5 \\
\hline 0 & $0 \cdot 7$ & $0 \cdot 7$ & $0 \cdot 7$ & 0 & 0 & 0 & 0 & 0 & 0 \\
\hline 24 & $1 \cdot 7$ & $1 \cdot 5$ & $1 \cdot 5$ & $34 \cdot 6$ & $42 \cdot 9$ & $37 \cdot 1$ & $20 \cdot 2$ & $29 \cdot 0$ & $25 \cdot 1$ \\
\hline 48 & $2 \cdot 4$ & $1 \cdot 8$ & $2 \cdot 1$ & $81 \cdot 6$ & $103 \cdot 7$ & $108 \cdot 8$ & $19 \cdot 2$ & $40 \cdot 0$ & $34 \cdot 3$ \\
\hline \multirow[t]{3}{*}{72} & $3 \cdot 2$ & $2 \cdot 8$ & $2 \cdot 5$ & $72 \cdot 7$ & $113 \cdot 4$ & $110 \cdot 8$ & 0 & $3 \cdot 5$ & $0 \cdot 8$ \\
\hline & \multicolumn{9}{|c|}{ (c) PMBN concn $\left(\mu \mathrm{g} \mathrm{ml}^{-1}\right)$} \\
\hline & 0 & $7 \cdot 5$ & 10 & 0 & $7 \cdot 5$ & 10 & 0 & $7 \cdot 5$ & 10 \\
\hline 0 & $0 \cdot 8$ & $0 \cdot 8$ & $0 \cdot 8$ & 0 & 0 & 0 & 0 & 0 & 0 \\
\hline 24 & $1 \cdot 8$ & $1 \cdot 5$ & $1 \cdot 6$ & $49 \cdot 2$ & $73 \cdot 4$ & $69 \cdot 4$ & $26 \cdot 7$ & $47 \cdot 7$ & $43 \cdot 4$ \\
\hline 48 & $2 \cdot 2$ & $2 \cdot 2$ & $2 \cdot 3$ & $79 \cdot 3$ & 93.4 & $106 \cdot 4$ & $13 \cdot 5$ & $8 \cdot 9$ & $16 \cdot 1$ \\
\hline 72 & $3 \cdot 3$ & $3 \cdot 1$ & $3 \cdot 2$ & $112 \cdot 8$ & $132 \cdot 2$ & $136 \cdot 3$ & $10 \cdot 2$ & $12 \cdot 6$ & $9 \cdot 3$ \\
\hline
\end{tabular}

* Mean value of two samples.

† Productivity of cells: the quantity of $\mathrm{AD}(\mathrm{D})$ formed during each $24 \mathrm{~h}$ interval was divided by the cell biomass obtained at the end of the interval.

formation of $\mathrm{AD}(\mathrm{D})$ started in the $24-48 \mathrm{~h}$ period, reaching the highest level at that time. In the presence of PEI, which was less inhibitory, the most pronounced bioconversion activity was also noticed in the $24-48 \mathrm{~h}$ interval; however, during the first $24 \mathrm{~h}$ the products were formed as in the control. With PMBN the enhancement in $\mathrm{AD}(\mathrm{D})$ formation reached its peak during the first $24 \mathrm{~h}$ and later it was maintained at the level of the control.

The variations in bioconversion activity of the compared cultures could be demonstrated more clearly in terms of cell productivity, i.e. the amount of products formed by a cell biomass unit [mg $\mathrm{AD}(\mathrm{D})$ (g dry biomass) $\left.^{-1}\right]$. At the highest points of activity, the quantities of $\mathrm{AD}(\mathrm{D})$ produced ranged from $40 \cdot 0$ to $79 \cdot 4 \mathrm{mg} \mathrm{AD}(\mathrm{D})$ (g dry biomass $)^{-1}$ in the presence of polycations, whereas in the control they did not exceed $26.7 \mathrm{mg} \mathrm{AD}(\mathrm{D})$ (g dry

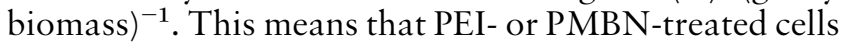

exceeded by twofold the activity of control cells, and the cells exposed to protamine were three times more active.

The enhanced bioconversion activity of $M$. vaccae $\mathrm{MB}$ 3683 seems unlikely to be due to a stimulatory effect of the polycations on the enzyme complex involved in the sterol side-chain cleavage. There is more evidence to support the assumption that the compounds affect the cell wall permeability to the sterol substrate. To confirm this suggestion, the sensitivity of the bacteria to antimycobacterial drugs alone and in combination with polycationic agents was determined in further experiments. It is generally agreed that low cell envelope permeability is one of the factors responsible for the well known drug resistance of mycobacteria. The drug sensitivity test has, therefore, been frequently used for the evaluation of the permeability barrier under conditions in which the barrier is expected to be weakened (Rastogi et al., 1990; Yuan et al., 1998; Mdluli et al., 1998). 

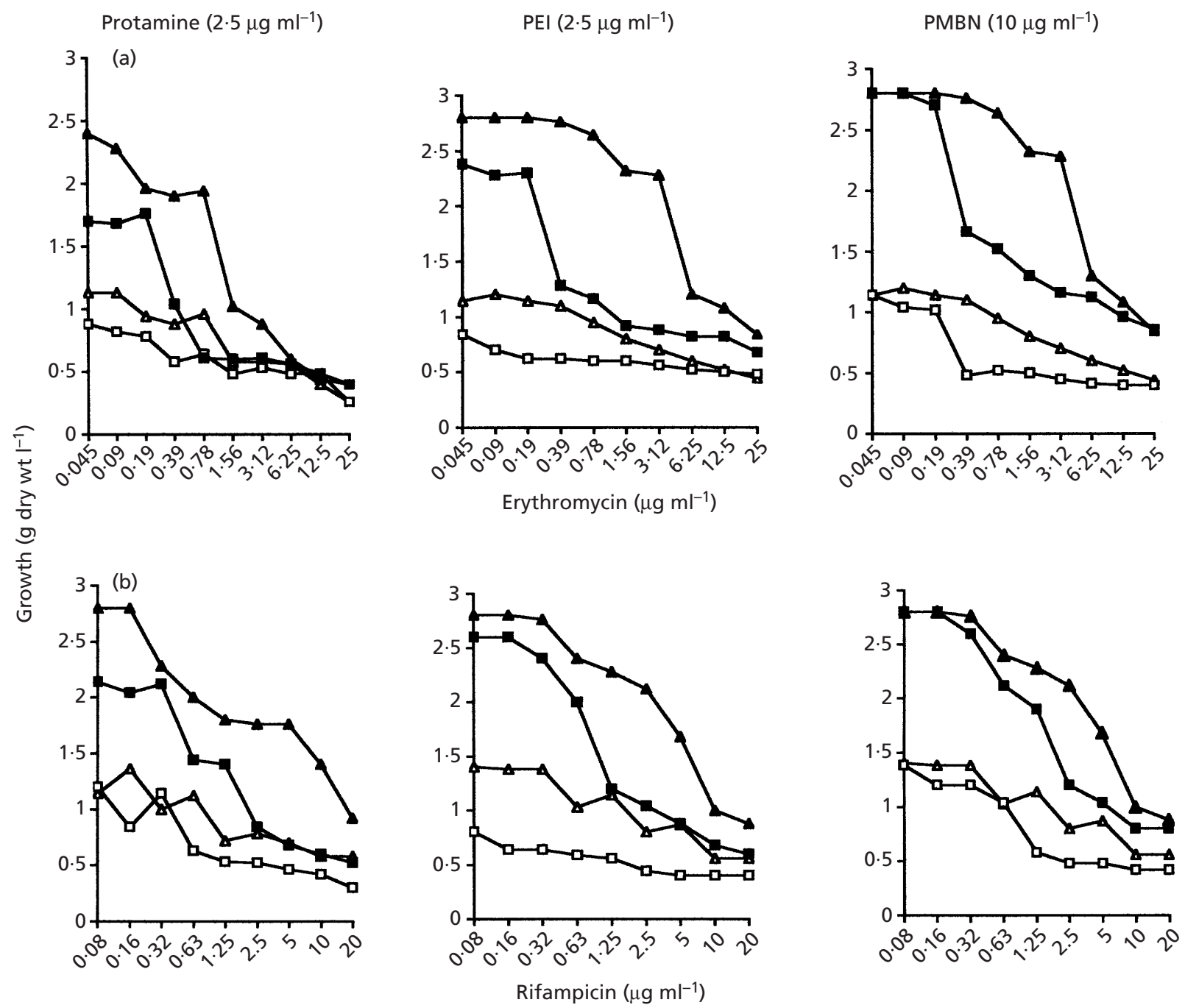

Fig. 1. Inhibition of $M$. vaccae $M B 3683$ growth by erythromycin (a) and rifampicin (b) with and without polycationic compounds. $\mathrm{OD}_{560}$ measurements of adequately diluted cultures were converted into cell dry biomass by the use of a standard graph depicting the relationship between the $\mathrm{OD}_{560}$ value and cell biomass content in the culture. Growth at $24 \mathrm{~h}$ with $(\square)$ and without $(\triangle)$ polycation. Growth at $48 \mathrm{~h}$ with $(\boldsymbol{\square})$ and without $(\boldsymbol{\Delta})$ polycation.

To minimize the inhibitory effect of polycations on cell growth, these experiments were performed at lower protamine and PEI concentrations.

\section{The effect of polycationic compounds on sensitivity to antibiotics}

The sensitivity of M. vaccae MB 3683 to rifampicin and erythromycin was shown in Fig. 1. The enhancement of antibiotic action by the polycationic compounds was observed in all tested combinations within $24 \mathrm{~h}$, but it was much stronger in $48 \mathrm{~h}$ cultures, in which cell growth was generally higher. M. vaccae MB 3683 proved resistant to both erythromycin and rifampicin. Even at the highest concentrations, the antibiotics did not stop growth and the MIC value could not be established. At lower concentrations, up to $0 \cdot 19 \mu \mathrm{g}$ erythromycin $\mathrm{ml}^{-1}$ (Fig. 1a) and 0.32-0.63 $\mu$ g rifampicin $\mathrm{ml}^{-1}$ (Fig. 1b), polycations produced a slight effect on growth in- hibition. Profound enhancement of antibiotic action by each of the compounds was observed at $0.39 \mu \mathrm{g}$ erythromycin $\mathrm{ml}^{-1}$ and $1 \cdot 25-2.5 \mu \mathrm{g}$ rifampicin $\mathrm{ml}^{-1}$. These concentrations could be regarded as $\mathrm{MIC}_{50}$ of the antibiotics in combination with polycations, as growth reached approximately half that of the control.

The $\mathrm{MIC}_{50}$ of the antibiotics alone was much higher, amounting to 1.56 and $6.25 \mu \mathrm{g}$ erythromycin $\mathrm{ml}^{-1}$, depending on growth intensity, and about $10 \mu \mathrm{g}$ rifampicin $\mathrm{ml}^{-1}$. The sensitization factor (Vaara, 1992), i.e. the approximate ratio between $\mathrm{MIC}_{50}$ for control bacteria and that exposed to polycations ranged from 4 to 16 in various combinations.

The results obtained in the drug sensitivity assay generally corresponded to those shown in Table 1.

The polycation-induced increase in sensitivity to antibiotics was evidently the result of synergistic growth 
Table 2. Growth inhibition of $M$. vaccae MB 3683 by polycationic compounds at the concentration used in the antibiotic sensitivity assay

The values represent the mean results of three independent experiments \pm SD.

\begin{tabular}{|c|c|c|c|c|}
\hline \multirow[t]{2}{*}{ Polycation } & \multicolumn{2}{|c|}{ Cell biomass ( $\mathrm{g}$ dry wt $\mathrm{l}^{-1}$ ) } & \multicolumn{2}{|c|}{ Inhibition (\%) } \\
\hline & $24 \mathrm{~h}$ & $48 \mathrm{~h}$ & $24 \mathrm{~h}$ & $48 \mathrm{~h}$ \\
\hline Control & $1 \cdot 4 \pm 0 \cdot 009$ & $2 \cdot 8 \pm 0 \cdot 007$ & 0 & 0 \\
\hline Protamine $\left(2 \cdot 5 \mu \mathrm{g} \mathrm{ml}^{-1}\right)$ & $1 \cdot 3 \pm 0 \cdot 005$ & $2 \cdot 7 \pm 0 \cdot 009$ & 7 & 4 \\
\hline PEI $\left(2 \cdot 5 \mu \mathrm{g} \mathrm{ml}^{-1}\right)$ & $1 \cdot 2 \pm 0 \cdot 007$ & $2 \cdot 6 \pm 0 \cdot 028$ & 14 & 7 \\
\hline PMBN $\left(10 \mu \mathrm{g} \mathrm{ml}^{-1}\right)$ & $1 \cdot 3 \pm 0 \cdot 025$ & $2 \cdot 7 \pm 0 \cdot 021$ & 7 & 4 \\
\hline
\end{tabular}

(a)

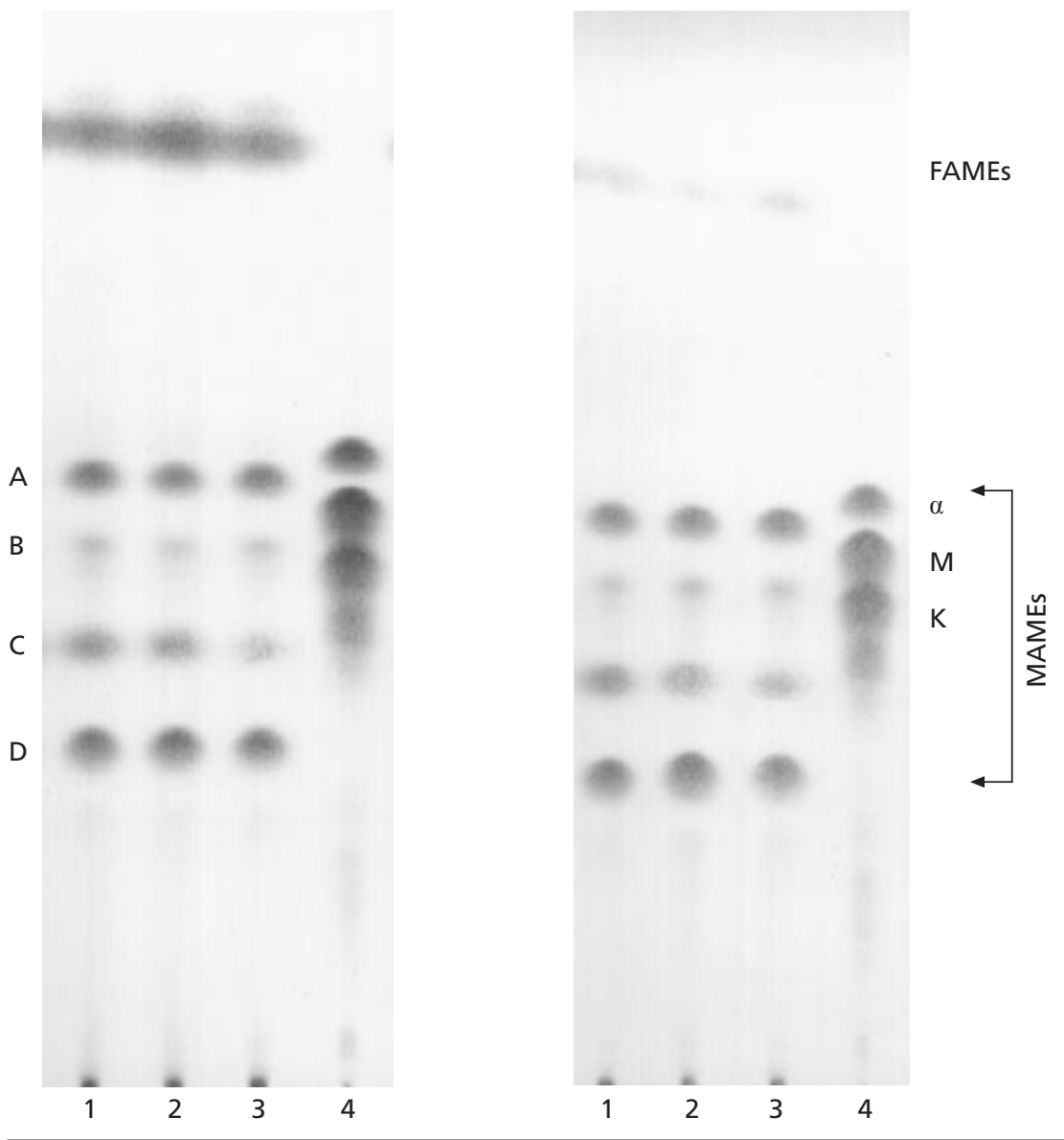

Fig. 2. Subclasses of $M$. vaccae $M B 3683$ mycolic acids. Whole lyophilized cells (a) and delipidated cells (b) were subjected to acid methanolysis according to Minnikin et al. (1980), the resulting cell-wall-linked MAMEs were purified on an ammonium hydrogen carbonate column, dried under nitrogen, weighed and separated on Merck silica gel 60 TLC plates using hexane/ethyl acetate $(94: 6, v / v)$ as the solvent system (five runs). In $M$. vaccae $\alpha_{-}, \alpha^{\prime}$-, keto- and carboxymycolates were recognized as mycolic acid subclasses (Kaneda et al., 1988, 1995; Valero-Guillen \& Martin-Luengo, 1986). The spots designated as A, B and D in our strain most probably correspond to these compounds ( $\alpha$ - and $\alpha^{\prime}$-mycolates do not separate easily in the solvent system used). Spot C was identified as 2-eicosanol by GC/MS (Sedlaczek et al., 1999). Lanes: 1-3, mycolates of protamine-treated, PEItreated and control cells, respectively. Lane 4, mycolic acid standards from M. tuberculosis. $\alpha, \mathrm{M}, \mathrm{K}, \alpha$-, methoxy- and ketomycolates, respectively. inhibition. In separate experiments it was shown that the polycations singly produced only slight growth inhibition (Table 2), which could not be responsible for the enhancement of antibiotic action.

\section{Assay of lipid alteration by fatty acid analysis}

To assess whether the observed enhancement in $\beta$ sitosterol bioconversion and sensitivity to antibiotics was reflected in cell wall lipid alteration, fatty acid analysis was performed separately for cell-wall-linked lipids (mycolates) and non-covalently bound (free) lipids.

\section{The effect of polycations on MAMEs}

Mycolic acid patterns of whole and delipidated cells of M. vaccae MB 3683, grown with or without polycations are shown in Fig. 2.

The mycolic acid patterns of control and polycationtreated whole (Fig. 2a) and delipidated (Fig. 2b) cells 
Table 3. Fatty acids and related compounds in extracts of methanolysates from defatted cells of $M$. vaccae MB 3683

Purified, dried MAME preparations were dissolved in ethyl acetate and analysed by GC/MS. The values are mean results of four to six independent measurements \pm SD.

\begin{tabular}{|c|c|c|c|c|c|c|}
\hline \multirow[t]{3}{*}{ Component } & \multicolumn{6}{|c|}{ Methanolysates of defatted: } \\
\hline & \multicolumn{2}{|c|}{ Control cells } & \multicolumn{2}{|c|}{ Protamine-treated cells } & \multicolumn{2}{|c|}{ PEI-treated cells } \\
\hline & $\mathrm{nmol} \mathrm{mg}^{-1}$ & $\operatorname{mol} \%$ & $\mathrm{nmol} \mathrm{mg}^{-1}$ & $\operatorname{mol} \%$ & $\mathrm{nmol} \mathrm{mg}^{-1}$ & $\operatorname{mol} \%$ \\
\hline $14: 0$ & $18 \cdot 7 \pm 0 \cdot 7$ & $6 \cdot 8$ & $16 \cdot 7 \pm 2 \cdot 2$ & $7 \cdot 8$ & $19 \cdot 5 \pm 0 \cdot 9$ & $6 \cdot 5$ \\
\hline $16: 1$ & & & & & $16 \cdot 6 \pm 0 \cdot 6$ & $5 \cdot 6$ \\
\hline $16: 0$ & $43 \cdot 2 \pm 1 \cdot 1$ & $15 \cdot 8$ & $32 \cdot 0 \pm 0 \cdot 6$ & $14 \cdot 9$ & $44 \cdot 6 \pm 1 \cdot 8$ & $15 \cdot 0$ \\
\hline $18: 1$ & $58 \cdot 8 \pm 3 \cdot 0$ & $21 \cdot 4$ & $39 \cdot 5 \pm 2 \cdot 2$ & $18 \cdot 3$ & $60 \cdot 0 \pm 6 \cdot 4$ & $20 \cdot 2$ \\
\hline 2-Eicosanol & $47 \cdot 7 \pm 1 \cdot 7$ & $17 \cdot 4$ & $42 \cdot 6 \pm 1 \cdot 5$ & $19 \cdot 8$ & $57 \cdot 9 \pm 2 \cdot 4$ & $19 \cdot 4$ \\
\hline $22: 0$ & $105 \cdot 8 \pm 4 \cdot 2$ & $38 \cdot 6$ & $84 \cdot 4 \pm 2 \cdot 5$ & $39 \cdot 2$ & $99 \cdot 0 \pm 3 \cdot 8$ & $33 \cdot 3$ \\
\hline Total & $274 \cdot 2$ & $100 \cdot 0$ & $215 \cdot 2$ & $100 \cdot 0$ & $297 \cdot 6$ & $100 \cdot 0$ \\
\hline
\end{tabular}

were similar. The same components appeared in all the analysed preparations which showed no qualitative changes under the action of the applied permeabilizers. To estimate possible quantitative differences, $100 \mathrm{mg}$ samples of delipidated cells were treated as for TLC analysis and the weights of the mycolates were compared. In three to four separate experiments, the following results were obtained: control cells, $8.96 \pm 0.73 \mathrm{mg}$; protamine-treated cells, $8.19 \pm 0.1 \mathrm{mg}$; and PEI-treated cells, $9 \cdot 10 \pm 0 \cdot 32 \mathrm{mg}$. The slight differences in mycolate weights remained within experimental error, which may suggest that the permeabilizers apparently did not affect the mycolic acid layer of the cell wall skeleton. Further experimental data confirming close similarities among the compared cellwall-linked mycolates were obtained in GC/MS determinations of their fatty acid profiles (Table 3).

Docosanoic acid (22:0) was the dominant component, present in each preparation in nearly the same amount. This fatty acid is formed as a methyl ester in situ upon pyrolysis of the complex mycolic acid structure in the heated injector of the gas chromatograph (GarciaBorcello et al., 1993). The $\alpha$-branch is released, which in $M$. vaccae contains mainly 22 carbon atoms (ValeroGuillen \& Martin-Luengo, 1986; Lechevalier et al., 1971). Similar quantities of this compound may result from similar content of mycolic acids in the analysed preparations. The same preparations were also analysed for $\mathrm{C}_{22: 0}$ content in pyrolysis $\mathrm{GC}$ with the injector temperature elevated to $390^{\circ} \mathrm{C}$. The injector port temperature of more than $350^{\circ} \mathrm{C}$ has been recommended for maximum cleavage of mycolic acids in pyrolysis GC (Kaneda et al., 1995). The obtained quantity of docosanoic acid was $89.5,78.7$ and $114.3 \mathrm{nmol} \mathrm{mg}{ }^{-1}$ for control, protamine- and PEItreated mycolate preparations. The figures are comparable for control mycolates and those exposed to polycations in both GC/MS and pyrolysis GC measure- ments, which may suggest that the content of these lipids was not altered in cells grown in polycation-containing media. 2-Eicosanol, a secondary alcohol present in mycobacteria that contain carboxymycolates (ValeroGuillen \& Martin-Luengo, 1986), was another component derived directly from mycolic acid cleavage. The compound also occurred in similar quantities, which strongly suggests that the composition of mycolic acids was not disturbed by the action of polycations.

\section{The effect of polycationic compounds, exemplified by protamine, on free lipids}

Non-covalently bound lipids, released by chloroform/ methanol $(2: 1, \mathrm{v} / \mathrm{v})$ extraction from two independent samples of both control and protamine-treated lyophilized cells, represented 12.55 and $16.15 \%$ (w/w) of the bacterial dry weights, respectively (mean values of two determinations). The fatty acids of the compared crude lipids ranged from 14 to 22 carbon atoms and were identified by GC/MS as tetradecanoic (14:0), hexadecenoic (16:1), hexadecanoic (16:0), octadecenoic (18:1), octadecanoic (18:0), 2-methyloctadecenoic (2Me 18:1), 10-methyloctadecanoic (tuberculostearic, 10Me 18:0), eicosanoic (20:0) and docosanoic (22:0) acids. The fatty acid composition of crude lipids in the two samples was essentially the same, the only difference was the lower quantity of 2-Me 18:1 and 20:0 in the preparation obtained from cells grown in the presence of protamine. Also, the total content of fatty acids in that lipid was higher than in control: 1687.7 and $1135.5 \mathrm{nmol} \mathrm{mg}^{-1}$, respectively.

Chloroform/methanol extracts contain a variety of lipids, including neutral lipids, glycolipids and phospholipids. To assess which of these lipids changed more in their fatty acid patterns, crude free lipids were fractionated on a silica gel column by successive use of chloroform, acetone and methanol as eluting solvents. 
(a)

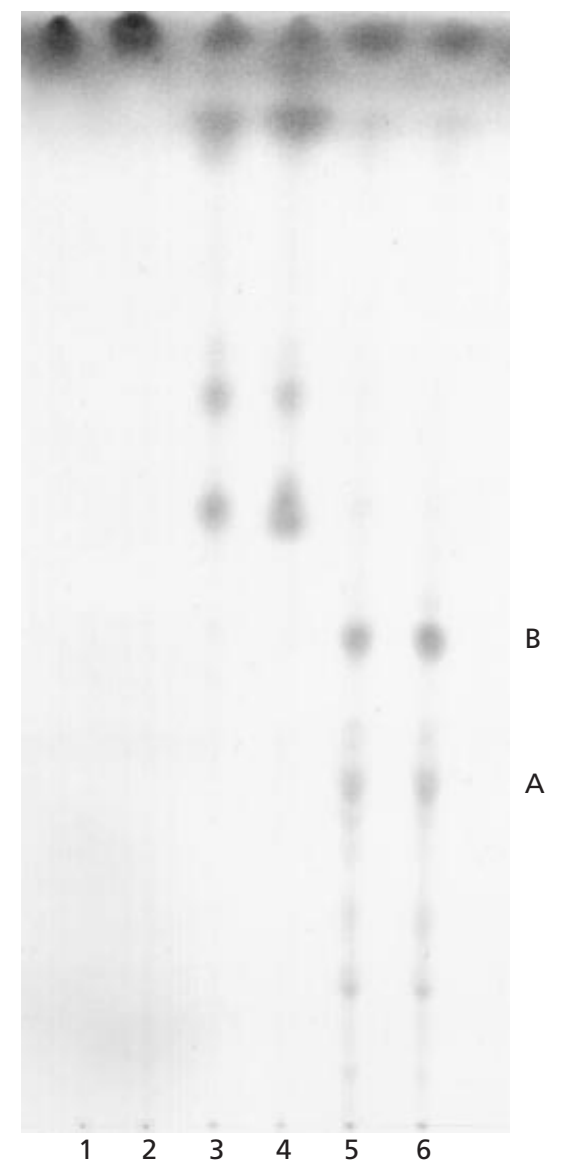

A (b)

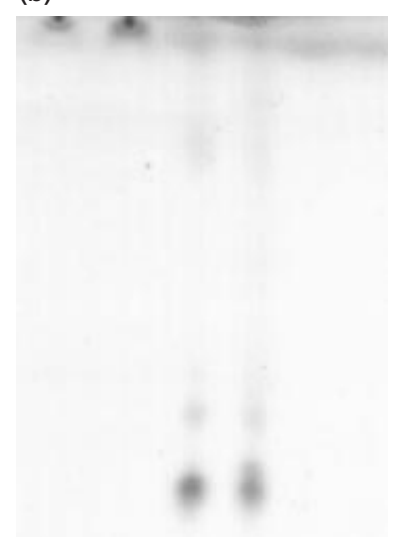

The separation of lipids was monitored by TLC. Fractions containing the same components were combined and analysed for sugar and phosphorus content. The chromatograms of combined solvent fractions are shown in Fig. 3.

Chloroform-derived material (moving with the front of the TLC developing system) contained mainly neutral lipids, i.e. glycerides, waxes, sterol esters, hydrocarbons, carotenoids, fatty acids and others (Koul \& Prasad, 1996); acetone-eluted lipids were composed mainly of glycolipids (positive reactions with both phosphomolybdate and orcinol) and methanol-eluted compounds were mainly phospholipids. The quantities of individual lipid fractions are shown in Table 4.

The overall quantities of lipids eluted from the silica gel 60 columns, 179.5 and $176.5 \mathrm{mg}$, respectively, were the same for both preparations and represented approximately $80 \%(\mathrm{w} / \mathrm{w})$ of the initial amount of free lipids. However, a distinct shift in the content of particular fractions was observed. There was only half the quantity of lipids eluted by chloroform from cells exposed to protamine compared to those in the control. On the other hand, a profound increase in acetone-derived lipids could be demonstrated in this free lipid preparation, which suggested protamine-induced disturb-
Table 4. Fractions of $M$. vaccae MB 3683 free lipids separated by successive use of chloroform, acetone and methanol

Free lipids $(230 \mathrm{mg})$ were subjected to fractionation from control and protamine-treated cells.

\begin{tabular}{|c|c|c|c|c|}
\hline \multirow[t]{3}{*}{ Eluant } & \multicolumn{4}{|c|}{ Lipids eluted from: } \\
\hline & \multicolumn{2}{|c|}{ Control cells } & \multicolumn{2}{|c|}{ Protamine-treated cells } \\
\hline & $\mathrm{mg}$ & $\%$ & mg & $\%$ \\
\hline Chloroform & $67 \cdot 7$ & $37 \cdot 7$ & $29 \cdot 5$ & $16 \cdot 7$ \\
\hline Acetone & $39 \cdot 0$ & $21 \cdot 7$ & $65 \cdot 9$ & $37 \cdot 3$ \\
\hline Methanol & $72 \cdot 8$ & $40 \cdot 6$ & $81 \cdot 1$ & $46 \cdot 0$ \\
\hline Total & $179 \cdot 5$ & $100 \cdot 0$ & $176 \cdot 5$ & $100 \cdot 0$ \\
\hline
\end{tabular}

ance in the composition of the complex lipids located in the outermost layer of the cell envelope. Methanoleluted fractions, mainly phospholipids, did not differ practically in quantity and composition. Further protamine-induced differentiation of the lipids was revealed by a comparative analysis of their fatty acid 
Table 5. Fatty acid composition of free lipid fractions from control and protaminetreated cells of $M$. vaccae MB 3683

The results are mean values obtained for four determinations \pm SD.

\begin{tabular}{|c|c|c|c|c|}
\hline \multirow[t]{2}{*}{ Component } & \multicolumn{2}{|c|}{ Control cells } & \multicolumn{2}{|c|}{ Cells exposed to protamine } \\
\hline & $\mathrm{nmol} \mathrm{mg}^{-1}$ & $\mathrm{~mol} \%$ & $\mathrm{nmol} \mathrm{mg}^{-1}$ & $\operatorname{mol} \%$ \\
\hline \multicolumn{5}{|c|}{ (a) Chloroform-eluted lipids } \\
\hline $16: 0$ & $51 \cdot 7 \pm 4 \cdot 5$ & $32 \cdot 6$ & $34 \cdot 0 \pm 1 \cdot 1$ & $40 \cdot 1$ \\
\hline $18: 1$ & $71 \cdot 0 \pm 6 \cdot 6$ & $44 \cdot 8$ & $50 \cdot 7 \pm 2 \cdot 5$ & $59 \cdot 9$ \\
\hline $18: 0$ & $15 \cdot 0 \pm 0 \cdot 9$ & $9 \cdot 5$ & & \\
\hline $22: 0$ & $20 \cdot 7 \pm 2 \cdot 0$ & $13 \cdot 1$ & & \\
\hline Total & $158 \cdot 4$ & $100 \cdot 0$ & $84 \cdot 7$ & $100 \cdot 0$ \\
\hline \multicolumn{5}{|c|}{ (b) Acetone-eluted lipids } \\
\hline $16: 1$ & $26 \cdot 5 \pm 1 \cdot 6$ & $7 \cdot 5$ & $80 \cdot 0$ & $12 \cdot 8$ \\
\hline $16: 0$ & $45 \cdot 5 \pm 1 \cdot 6$ & $12 \cdot 8$ & $109 \cdot 5 \pm 5 \cdot 2$ & $17 \cdot 6$ \\
\hline $18: 1$ & $80 \cdot 3 \pm 3 \cdot 6$ & $22 \cdot 7$ & $298 \cdot 3 \pm 15 \cdot 1$ & $47 \cdot 9$ \\
\hline $18: 0$ & $25 \cdot 8 \pm 0 \cdot 2$ & $7 \cdot 3$ & $27 \cdot 3 \pm 2 \cdot 8$ & $4 \cdot 4$ \\
\hline 2-Me 18:1 & Trace & & $24 \cdot 0$ & $3 \cdot 9$ \\
\hline $20: 0$ & $24 \cdot 0 \pm 0 \cdot 9$ & $6 \cdot 8$ & $31 \cdot 3 \pm 4 \cdot 5$ & $5 \cdot 0$ \\
\hline $22: 0$ & $152 \cdot 0 \pm 6 \cdot 2$ & $42 \cdot 9$ & $52 \cdot 3 \pm 7 \cdot 5$ & $8 \cdot 4$ \\
\hline Total & $354 \cdot 1$ & $100 \cdot 0$ & $622 \cdot 7$ & $100 \cdot 0$ \\
\hline \multicolumn{5}{|c|}{ (c) Methanol-eluted lipids } \\
\hline $14: 0$ & $24 \cdot 8 \pm 1 \cdot 6$ & $3 \cdot 2$ & $12 \cdot 5$ & $1 \cdot 8$ \\
\hline $16: 1$ & $85 \cdot 0 \pm 5 \cdot 5$ & $11 \cdot 1$ & $102 \cdot 5 \pm 6 \cdot 6$ & $14 \cdot 5$ \\
\hline $16: 0$ & $262 \cdot 0 \pm 17 \cdot 9$ & $34 \cdot 3$ & $258 \cdot 7 \pm 16 \cdot 2$ & $36 \cdot 5$ \\
\hline $18: 1$ & $328 \cdot 0 \pm 23 \cdot 6$ & $42 \cdot 9$ & $271 \cdot 5 \pm 21 \cdot 9$ & $38 \cdot 3$ \\
\hline $18: 0$ & $18 \cdot 6 \pm 0 \cdot 5$ & $2 \cdot 4$ & $11 \cdot 5$ & $1 \cdot 6$ \\
\hline 10-Me 18:0 & $47 \cdot 0 \pm 3 \cdot 3$ & $6 \cdot 1$ & $51 \cdot 7 \pm 3 \cdot 3$ & $7 \cdot 3$ \\
\hline Total & $765 \cdot 4$ & $100 \cdot 0$ & $708 \cdot 4$ & $100 \cdot 0$ \\
\hline
\end{tabular}

content. The GC/MS measurements of fatty acids of the particular lipid fractions are shown in Table 5.

Chloroform-eluted lipids (Table 5a) contained mainly $\mathrm{C}_{16}$ and $\mathrm{C}_{18}$ components, which comprised more than $85 \%(\mathrm{w} / \mathrm{w})$ of the total in the control and $100 \%$ in protamine-treated cells. The total quantity of fatty acids in the control was double that of the 'protamine' neutral lipids, in line with the results of free lipid fractionation (Table 4), showing a decrease in neutral lipid content for the cells exposed to protamine. Neutral lipids from protamine-treated cells appeared to be reduced both in quantity and fatty acid profile.

Significant quantitative differences in fatty acid patterns of the analysed preparations also occurred for glycolipids eluted by acetone (Table 5b). Docosanoic acid (22:0) was the main component of the control cell glycolipids. This indicated a high level of mycolatecontaining compounds, mainly trehalose mycolates, in this lipid fraction. Trehalose mycolates are known to be commonly present in mycobacterial free lipids. In the cells exposed to protamine, docosanoic acid occurred at a markedly lower level, which may have resulted from either less effective biosynthesis of mycolate-containing lipids or their faster removal from the outermost cell layer into the medium in the presence of protamine. A very high level of octadecenoic acid $(18: 1)$ was another feature of the fatty acid profile of these lipids. Contrary to mycolates, which play a crucial part in forming the permeability barrier, unsaturated fatty acids of moderate hydrocarbon chain length increase lipid fluidity and thereby facilitate penetration of compounds through lipid layers. The observed shift in fatty acid composition under the action of protamine may be of importance in the context of the demonstrated enhanced penetrability of $\beta$-sitosterol and hydrophobic antibiotics through the cell wall lipid domain. It is also worth noting that the acetone-eluted lipids of protaminetreated cells were twice as rich in fatty acids than the control ones. It may be inferred from these results that in the presence of protamine, an evident change in both the relative quantities of various lipids and their fatty acid composition occurred, which could in turn affect the permeability properties of free lipids.

Methanol-eluted lipids (Table 5c), consisting mainly of phospholipids, remained without noticeable changes in their fatty acid composition and relative quantities in 
Table 6. Fatty acid composition of after-growth of control and protamine-containing cultures of $M$. vaccae MB 3683

The after-growth medium $(100 \mathrm{ml})$ was extracted with chloroform/methanol $(2: 1, \mathrm{v} / \mathrm{v})$ and subjected to acid methanolysis. The methanolysate extracts were analysed for their fatty acid content. The weight of the medium methanolysate extracts was approximately one-fifth that of the cell biomass obtained from an adequate volume of the medium; thus, the quantity of total fatty acids revealed in the post-culture media is approximately one-fifth that of cell biomass. The results are mean values obtained for three determinations \pm SD.

\begin{tabular}{|c|c|c|c|c|c|c|}
\hline \multirow[t]{3}{*}{ Component } & \multicolumn{6}{|c|}{ Fatty acids obtained from: } \\
\hline & \multicolumn{2}{|c|}{ Whole-cell lipids } & \multicolumn{2}{|c|}{ Control post-culture medium } & \multicolumn{2}{|c|}{ Protamine-containing post-culture medium } \\
\hline & $\mathrm{nmol} \mathrm{mg}^{-1}$ & $\mathrm{~mol} \%$ & $\mathrm{nmol} \mathrm{mg}^{-1}$ & $\mathrm{~mol} \%$ & $\mathrm{nmol} \mathrm{mg}^{-1}$ & $\mathrm{~mol} \%$ \\
\hline 14:0 & $23 \cdot 2$ & $2 \cdot 8$ & & & $62 \cdot 3$ & $3 \cdot 5$ \\
\hline $16: 1$ & $79 \cdot 9$ & $9 \cdot 5$ & & & $155 \cdot 7 \pm 24 \cdot 7$ & $8 \cdot 9$ \\
\hline $16: 0$ & $220 \cdot 8$ & $26 \cdot 3$ & & & $124 \cdot 7 \pm 8 \cdot 3$ & $7 \cdot 1$ \\
\hline 2-Me 16:1 & & & $51 \cdot 4 \pm 2 \cdot 8$ & $3 \cdot 9$ & & \\
\hline $18: 1$ & $285 \cdot 8$ & $34 \cdot 0$ & $51 \cdot 0 \pm 9 \cdot 6$ & $3 \cdot 8$ & $479 \cdot 2 \pm 52 \cdot 0$ & $27 \cdot 3$ \\
\hline $18: 0$ & $22 \cdot 3$ & $2 \cdot 7$ & $20 \cdot 6 \pm 0 \cdot 6$ & $1 \cdot 6$ & $93 \cdot 6 \pm 11 \cdot 4$ & $5 \cdot 3$ \\
\hline 2-Me 18:1 & $19 \cdot 2$ & $2 \cdot 3$ & $483 \cdot 7 \pm 17 \cdot 8$ & $36 \cdot 4$ & & \\
\hline 10-Me 18:0 & $57 \cdot 0$ & $6 \cdot 8$ & & & & \\
\hline $20: 0$ & $21 \cdot 4$ & $2 \cdot 5$ & $261 \cdot 0 \pm 9 \cdot 4$ & $19 \cdot 6$ & $101 \cdot 2 \pm 1 \cdot 8$ & $5 \cdot 8$ \\
\hline $22: 1$ & & & $35 \cdot 0 \pm 2 \cdot 8$ & $2 \cdot 6$ & & \\
\hline $22: 0$ & $110 \cdot 5$ & $13 \cdot 1$ & $426 \cdot 2 \pm 12 \cdot 3$ & $32 \cdot 1$ & $738 \cdot 8 \pm 27 \cdot 2$ & $42 \cdot 1$ \\
\hline Total & $840 \cdot 1$ & $100 \cdot 0$ & $1328 \cdot 9$ & $100 \cdot 0$ & $1755 \cdot 5$ & $100 \cdot 0$ \\
\hline
\end{tabular}

control and under the action of protamine. The presence of tuberculostearic acid (10-Me 18:0) among the fatty acids indicated that a part of the phospholipids were located in the cell wall. This fatty acid is believed to differentiate between the cell wall and the membrane phospholipids (Rastogi, 1991).

To determine whether protamine had an effect on cell lysis or an increased discharge of surface lipid components into the medium, the after-growth medium was analysed for fatty acid composition. The comparative fatty acid patterns of the whole-cell lipids and the aftergrowth media of control and protamine-treated cultures are shown in Table 6.

The fatty acid composition of the control post-culture medium did not reflect the fatty acid profile of the whole-cell lipids, which suggested that these compounds appeared in the medium as a result of selective removal of the cell wall surface components rather than cell lysis. Lipid compounds containing 2-methyl branched octadecenoic acid (2-Me 18:1) and long hydrocarbon chain acids, eicosanoic $(20: 0)$ and docosanoic $(22: 0)$ acids, accumulated in the medium to much higher relative concentrations than those occurring in whole-cell lipids. High content of 22:0 could indicate that it was glycolipids that were preferentially released from the cell surface.

The fatty acid pattern of the protamine-containing after-growth medium was closer to that of the wholecell lipids, which suggested that little cell lysis occurred in that culture. The elevated level of the overall fatty acid content $\left(1755.5 \mathrm{nmol} \mathrm{mg}{ }^{-1}\right)$ was in agreement with this assumption. Octadecenoic $(18: 1)$ and docosanoic (22:0) acids were dominant. 18:1 was the most abundant component in all free lipid fractions (Table 5) while 22:0 was characteristic for glycolipids. Its exceptionally high content in the after-growth medium, accompanied by an evidently smaller quantity in the acetone-eluted lipid fraction (Table 5b), could be explained by enhanced removal of mycolate-containing glycolipids from protamine-treated cells, as compared to control.

\section{DISCUSSION}

The very low cell wall permeability of mycobacteria is considered to be a result of the composition of cell wall lipids and their organization as an asymmetric bilayer, the internal leaflet of which is composed of mycolic acids. As expected from their chemical structure, the deepest part of those acids, comprising approximately 20 carbon chains away from the carboxyl end, forms a region of extremely low fluidity, responsible for the permeability barrier to solutes (Brennan \& Nikaido, 1995; Liu et al., 1995, 1996). This assumption received support from biophysical studies, including X-ray diffraction analysis of purified $M$. chelonae cell wall (Nikaido et al., 1993), determination of phase transition temperatures of cell wall lipids and electron spin resonance (ESR) measurement of cell wall labelled with spin-labelled fatty acid probes (Liu et al., 1995, 1996).

It is only recently that the function of mycolic acids as the permeability barrier in mycobacteria has been confirmed by studies including direct measurements of the uptake of compounds by mycobacterial cells with 
altered mycolate content or composition. An M. tuberculosis mutant strain with an inactivated gene encoding antigen $85 \mathrm{C}$, a protein associated with mycoloyl transferase activity, transferred $40 \%$ less mycolates on arabinogalactan than its parent strain. A significant decrease in the amount of cell-wall-linked mycolic acids resulted in enhanced chenodeoxycholate and glycerol uptake by the mutant strain, which indicated that the normally higher content of mycolic acids obstructed the access of these compounds into the cell (Jackson et al., 1999). Similar results were obtained for the csp-1 inactivated mutant of Corynebacterium glutamicum, deficient in PS1 protein which is similar to the antigen 85 complex of M. tuberculosis. This mutant lacked $50 \%$ of cell-wall-bound corynemycolates and it exhibited an initial rate of glycerol and acetate uptake that was considerably higher than that of the parent strain. These results confirmed the importance of the amount of cell-wall-linked mycolates for cell envelope permeability (Puech et al., 2000).

The treatment of Mycobacterium avium with isoniazid at concentrations that would disturb mycolic acid synthesis, producing no effect on growth, heightened the cells sensitivity to hydrophobic rifampicin (Mdluli et al., 1998) which is in line with the data presented above. Apart from the overall amount of cell-wall-linked mycolates, the relative proportion of $\alpha$-, keto- and methoxy-mycolates, the three classes of mycolates occurring in M. tuberculosis, has been shown to be of importance. A modification made in mycolate composition, consisting in the substitution of keto-mycolates with methoxy-mycolates in mma-3-transformed $M$. tuberculosis and BCG strains, resulted in a significant drop in glucose uptake and a marked increase in the sensitivity of the recombinant strains to ampicillin and rifampicin (Yuan et al., 1998). The transformed organisms were able to overproduce functional MMA-3 protein, a methyltransferase determining the methoxymycolate level.

The influence of oxygenated mycolic acids on cell envelope permeability was also demonstrated by Dubnau et al. (2000), using a mutant strain of $M$. tuberculosis $\mathrm{H} 37 \mathrm{Rv}$ with an inactivated hma gene. Although the mutant produced a similar amount of mycolates as its isogenic parent strain, it no longer synthesized keto- and methoxy-mycolates. As a result, it displayed a much lower initial rate of uptake and accumulation of chenodeoxycholate and glycerol. This is because oxygenated mycolates confer a marked fluidity to the cell wall and facilitate permeation of these substrates in the parent strain.

In the present study, the enhanced penetration of compounds through the cell envelope was demonstrated in M. vaccae with no alteration in the cell-wall-bound mycolic acid composition and quantity, which suggests that these mycolates are not involved in the change in permeability due to the polycations.

This may be a consequence of a considerable difference in $M$. vaccae mycolate structure, fluidity and permeability. For most other mycobacterial species which have been recognized to possess a potent diffusion barrier to drugs and other molecules, a high proportion of the proximal double bond of the meromycolate chain (16-20 carbons away from the carboxyl group) in $\alpha$ mycolates is converted to the trans configuration (Brennan \& Nikaido, 1995). This configuration favours crystalline arrangement of the hydrocarbon chain and confers extremely low fluidity on the inner section of mycolates (Liu et al., 1996). In contrast, M. vaccae contains more than $90 \%$ cis-double bonds at the proximal position of mycolates, which are expected to introduce kinks disrupting the tight lateral packing of the hydrocarbon chains. As a result, the permeability barrier of $M$. vaccae is not as strong as in other mycobacteria.

The results obtained in our study suggest that the $M$. vaccae complex lipids, forming the outer leaflet of the cell wall bilayer, may contribute to the permeability barrier. The enhanced uptake of $\beta$-sitosterol and hydrophobic antibiotics in the presence of protamine was accompanied by an evident disorganization of the native arrangement of non-covalently bound lipids. This was expressed in the alteration of the relative proportion of chloroform- and acetone-eluted free lipid fractions, as well as in general changes to their fatty acid composition. The most important of the latter was the enrichment of the acetone fraction in unsaturated fatty acids of moderate hydrocarbon chain length and a significant decrease in docosanoic acid (22:0), the marker compound of mycolate-containing glycolipids. This may reflect partial disturbance of the natural assembly of the cell surface complex lipids, which may in turn result in altered permeability features.

Despite a good general knowledge of the chemical composition of the mycobacterial cell envelope, many details remain to be elucidated, particularly those regarding the organization and physiological function of non-covalently bound lipids (Jackson et al., 1999). Some of them are certainly involved in the mycobacterial permeability barrier (Puech et al., 2000). In M. vaccae these lipids may include mycolate glycolipids and other components that contain fatty acids of relatively long hydrocarbon chain-length, poor in double bonds.

The fluidity of the outer leaflet of the mycobacterial cell wall bilayer, though moderate, is lower than that of the common phospholipid bilayer of the cell membrane (Liu et al., 1995). Hence, this lipid layer is likely to contain regions forming a partial permeability barrier, which may be disrupted by biochemical agents, enabling enhanced diffusion of solutes. Using $m$-fluorophenylalanine that specifically inhibited the biosynthesis of mycoside C (David et al., 1988), a component of the outer layer in M. chelonae, Rastogi et al. (1990) demonstrated that, without increased cell lysis, the disorganization of the outer layer resulted in an enhanced entry of rifampicin, ciprofloxacin and other drugs into the cell and sensitization of cells to these compounds. The same inhibitor was also shown to have 
an effect on the enhancement of $\beta$-sitosterol transformation by M. vaccae (Rumijowska et al., 2000).

Our present results confirm this function of the outer layer through the application of polycationic compounds, which act in a different manner. In Gramnegative bacteria, the molecular mechanism of the increase in OM permeability is thought to consist of the binding of polycations with negatively charged components and their intercalation in the OM bilayer, the effect of which is an increase in the membrane surface area and changes to its physical structure (Vaara, 1992; Helander et al., 1997, 1998). Some polycations were shown to partially release LPS from the OM into the growth medium. The losses are thought to be compensated for by phospholipids, which results in the formation of diffusion channels.

It is difficult to give a definitive interpretation of the polycation-increased permeability of $M$. vaccae envelopes, but it most probably involves a mechanism similar to that recognized in Gram-negative bacteria. Complex lipids forming the outermost cell wall layer contain a number of negative charges which enable binding of polycations and, as a consequence, alter interactions between the components, analogous to the altered LPS-LPS interactions in Gram-negative bacteria.

The change in the relative proportion of the chloroformand acetone-eluted free lipid fractions observed in our study, as well as modifications in their fatty acid composition, may likely be a secondary effect of the disturbance in the natural distribution and assembly of cell wall complex lipids. This may in turn account for the disruption of the permeability barrier function of this part of M. vaccae cell envelopes.

\section{ACKNOWLEDGEMENT}

This work was supported by grant 6 PO4B 01914 of the Committee for Scientific Research.

\section{REFERENCES}

Ariza, M. A., Martin-Luengo, F. \& Valero-Guillen, P. L. (1994). A family of diacyltrehaloses isolated from Mycobacterium fortuitum. Microbiology 140, 1898-1994.

Besra, G. S. \& Chatterjee, D. (1994). Lipids and carbohydrates of Mycobacterium tuberculosis. In Tuberculosis: Pathogenesis, Protection, and Control, pp. 285-306. Edited by B. Bloom. Washington, DC: American Society for Microbiology.

Brennan, P. J. (1988). Mycobacterium and other actinomycetes. In Microbial Lipids, vol. 1, pp. 251-278. Edited by C. Ratledge \& S. G. Wilkinson. London: Academic Press.

Brennan, P. J. \& Nikaido, H. (1995). The envelope of mycobacteria. Annu Rev Biochem 64, 29-63.

Brzostek, A. M., Pawłowicz, M. \& Dziadek, J. (2001). The DNA probe and PCR assay as useful tools to control an acid fast bacteria-dependent biotechnological process. Acta Microbiol Pol 50, 37-44.

Christensen, H., Garton, N. J., Horobin, R. W., Minnikin, D. E. \& Barer, M. R. (1999). Lipid domains of mycobacteria studied with fluorescent molecular probes. Mol Microbiol 31, 1561-1572.
Daffé, M. \& Draper, P. (1998). The envelope layers of mycobacteria with reference to their pathogenicity. Adv Microb Physiol 39, 131-203.

David, H. L., Rastogi, N., Clavel-Seres, S. \& Clement, F. (1988). Alteration in the outer wall architecture caused by the inhibition of mycoside C biosynthesis in Mycobacterium avium. Curr Microbiol 17, 61-68.

Dubnau, E., Chan, J., Raynaud, C., Mohan, V. P., Laneelle, M. A., Yu, K., Quemard, A., Smith, I. \& Daffé, M. (2000). Oxygenated mycolic acids are necessary for virulence of Mycobacterium tuberculosis in mice. Mol Microbiol 36, 630-637.

Gamian, A., Mordarska, H., Ekiel, I., Ulrich, J., Szponar, B. \& Defaye, J. (1996). Structural studies of the major glycolipid from Saccharopolyspora genus. Carbohydr Res 296, 55-67.

Garcia-Borcelo, M., Luquin, M., Belda, F. \& Ausina, V. (1993). Gas chromatographic whole-cell fatty acid analysis as an aid for the identification of mixed mycobacterial cultures. J Chromatogr 617, 299-303.

Helander, I. M., Alakomi, H.-L., Latva-Kala, K. \& Koski, P. (1997). Polyethyleneimine is an effective permeabilizer of Gram-negative bacteria. Microbiology 143, 3193-3199.

Helander, I. M., Latva-Kala, K. \& Lounatmaa, K. (1998). Permeabilizing action of polyethyleneimine on Salmonella typhimurium involves disruption of the outer membrane and interactions with lipopolysaccharide. Microbiology 144, 385-390.

Jackson, M., Raynaud, C., Lanéelle, M. A., Guilhot, Ch., LaurentWinter, Ch., Ensergueix, D., Gicquel, B. \& Daffé, M. (1999). Inactivation of the antigen $85 \mathrm{C}$ gene profoundly affects the mycolate content and alters the permeability of the $\mathrm{Myco-}$ bacterium tuberculosis cell envelope. Mol Microbiol 31, 1573-1587.

Jarlier, V. \& Nikaido, H. (1990). Permeability barrier to hydrophilic solutes in Mycobacterium chelonae. J Bacteriol 172, 1418-1423.

Kaneda, K., Imaizumi, S., Mizuno, S., Baba, T., Tsukamura, M. \& Yano, I. (1988). Structure and molecular species composition of three homologous series of $\alpha$-mycolic acids from Mycobacterium sp. J Gen Microbiol 134, 2213-2229.

Kaneda, K., Imaizumi, S. \& Yano, I. (1995). Distribution of $\mathrm{C}_{22^{-}}$,

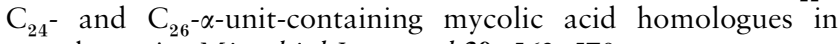
mycobacteria. Microbiol Immunol 39, 563-570.

Koul, A. \& Prasad, R. (1996). Extraction of membrane lipids. In Manual on Membrane Lipids, pp. 36-51. Edited by R. Prasad. Berlin, Heidelberg: Springer.

Lechevalier, M. P., Horan, A. C. \& Lechevalier, H. (1971). Lipid composition in the classification of nocardiae and mycobacteria. J Bacteriol 105, 313-318.

Liu, J., Barry, C. E., Besra, G. S. \& Nikaido, H. (1996). Mycolic acid structure determines the fluidity of the mycobacterial cell wall. $J$ Biol Chem 271, 29545-29551.

Liu, J., Rosenberg, E. Y. \& Nikaido, H. (1995). Fluidity of the lipid domain of cell wall from Mycobacterium chelonae. Proc Natl Acad Sci U S A 92, 11254-11258.

Mdluli, K., Swanson, J., Fischer, E., Lee, R. E. \& Barry, C. E., III (1998). Mechanisms involved in the intrinsic isoniazid resistance of Mycobacterium avium. Mol Microbiol 27, 1223-1233.

Minnikin, D. E. (1982). Lipids: complex lipids, their chemistry, biosynthesis and roles. In The Biology of the Mycobacteria, vol. 1, pp. 95-184. Edited by C. Ratledge \& J. Stanford. London: Academic Press.

Minnikin, D. E., Hutchinson, G., Caldicott, A. B. \& Goodfellow, M. (1980). Thin-layer chromatography of methanolysates of mycolic acid-containing bacteria. J Chromatogr 188, 221-233. 
Nikaido, H., Kim, S.-H. \& Rosenberg, E. Y. (1993). Physical organization of lipids in the cell wall of Mycobacterium chelonae. Mol Microbiol 8, 1025-1030.

Plesiat, P. \& Nikaido, H. (1992). Outer membranes of Gramnegative bacteria are permeable to steroid probes. Mol Microbiol 6, 1323-1333.

Puech, V., Bayan, N., Salim, K., Leblan, G. \& Daffé, M. (2000). Characterization of the in vivo acceptors of the mycoloyl residues transferred by the corynebacterial PSI and the related mycobacterial antigen 85. Mol Microbiol 35, 1026-1041.

Rastogi, N. (1991). Recent observations concerning structure and function relationships in the mycobacterial cell envelope: elaboration of a model in terms of mycobacterial pathogenicity, virulence and drug-resistance. Res Microbiol 142, 464-476.

Rastogi, N., Goh, K. S. \& David, H. L. (1990). Enhancement of drug susceptibility of Mycobacterium avium by inhibitors of cell envelope synthesis. Antimicrob Agents Chemother 34, 759-764.

Rumijowska, A., Lisowska, K., Ziółkowski, A. \& Sedlaczek, L. (1997). Transformation of sterols by Mycobacterium vaccae: effect of lecithin on the permeability of cell envelopes to sterols. World J Microbiol Biotechnol 13, 89-95.

Rumijowska-Galewicz, A., Ziółkowski, A., Korycka-Machała, M. \& Sedlaczek, L. (2000). Alterations in lipid composition of Mycobacterium vaccae cell wall outer layer enhance $\beta$-sitosterol degradation. World J Biol Biotechnol 16, 237-244.
Sedlaczek, L., Górmiński, B. \& Lisowska, K. (1994). Effect of inhibitors of cell envelope synthesis on $\beta$-sitosterol side chain degradation by Mycobacterium sp. MB 3683. J Basic Microbiol 34, 387-399.

Sedlaczek, L., Lisowska, K., Korycka, M., Rumijowska, A., Ziółkowski, A. \& Długoński, J. (1999). The effect of cell wall components on glycine-enhanced sterol side chain degradation to androstene derivatives by mycobacteria. Appl Microbiol Biotechnol 52, 563-571.

Szentirmai, A. (1990). Microbial physiology of side chain degradation of sterols. J Ind Microbiol 6, 101-115.

Vaara, M. (1992). Agents that increase the permeability of the outer membrane. Microbiol Rev 56, 395-411.

Valero-Guillen, P. L. \& Martin-Luengo, F. (1986). 1-Tetradecanol, a new alcohol found in the cell wall of some rapidly growing chromogenic mycobacteria. FEMS Microbiol Lett 35, 59-63.

Vestal, J. R. \& Perry, J. J. (1971). Effect of substrate on the lipids of the hydrocarbon-utilizing Mycobacterium vaccae. Can J Microbiol 17, 445-449.

Yuan, Y., Zhu, Y., Crane, D. D. \& Barry, C. E., III (1998). The effect of oxygenated mycolic acid composition on cell wall function and macrophage growth in Mycobacterium tuberculosis. Mol Microbiol 29, 1449-1458.

Received 5 April 2001; revised 15 June 2001; accepted 21 June 2001. 